\title{
Sentidos do abuso sexual intrafamiliar para adolescentes do sexo feminino
}

\author{
Meanings intrafamilial sexual abuse for female adolescents
}

\author{
Juliana Hilario Maranhão* \\ Alessandra Silva Xavier**
}

\begin{abstract}
Resumo:
Este artigo surgiu a partir do estudo monográfico Resiliência e Violência Sexual: um estudo sobre adolescentes vitimizadas por abuso sexual intrafamiliar (MARANHÃO, 2008), no qual se investigou a construção de resiliência em adolescentes vitimizadas. A resiliência é caracterizada como superação de situações adversas, configurando-se como algo processual, promovida pela interação de fatores de proteção pessoais e coletivos, em determinado contexto de risco ou vulnerabilidade social. Fizemos o recorte sobre os significados e sentidos da vitimização sexual intrafamiliar a partir da percepção das adolescentes entre 12 e 16 anos de idade atendidas em um Centro de Referência Especializado de Assistência Social no ano de 2010. A pesquisa é de caráter qualitativo tendo como referencial teórico-metodológico a Teoria Histórico-Cultural. $\mathrm{Na}$ coleta de dados, foi utilizada entrevista semiestruturada. Percebemos que o perfil das vítimas é configurado pelo gênero feminino e o início do abuso sexual ocorreu entre a infância e pré-adolescência. Já o perfil dos agressores é de homens adultos, exercendo as funções familiares de padrasto, pai e tio. Apesar de um sentimento abjeto, as adolescentes não conseguiam romper com o ciclo de violência. Os amigos, a família ampliada, e o trabalho de profissionais surgiram como suporte para a ressignificação da relação abusiva.
\end{abstract}

Palavras-chave: Violência sexual; Abuso sexual intrafamiliar; Adolescência; Sentidos; Resiliência

\begin{abstract}
:
This article came from the monographic study "Resilience and Sexual Violence: a study of adolescents victimized by sexual abuse assistance" (MARANHÃO, 2008), in which was investigated the building resilience in victimized adolescents. Resilience is characterized as overcoming adversity, setting up as something procedural, promoted by the interaction of personal and collective protection, in particular context of risk or social vulnerability. We made the trimming about the meanings and feelings of sexual victimization within the family from the perception of adolescents between 12 and 16 years of age that received care in a Specialized Reference Social Assistance in 2010. The research is qualitative, having as theoretical-methodological referential the
\end{abstract}

\footnotetext{
* Graduada em Serviço Social pela Universidade Estadual do Ceará. Mestranda em Psicologia pela Universidade Federal do Ceará. Integrante do Núcleo Cearense de Estudos e Pesquisas sobre a Criança- NUCEPEC. E-mail: juliana-maranhao@hotmail.com

** Psicóloga. Mestre em Educação pela Universidade Federal do Ceará. Professora do curso de Psicologia da Universidade Estadual do Ceará. E-mail: asxavier@gmail.com
} 
Historic-Cultural Theory. Data collection was used by semi-structured interview. We realize that the profile of the victims are set up by females, the beginning of sexual abuse occurred between childhood and preadolescence. The profile of perpetrators are men, adults, acting the role of the stepfather, father and uncle. Despite an abject sense, adolescents could not break the cycle of violence. Friends, extended family, and the work of professionals emerged as support for the redefinition of the abusive relationships.

Keywords: Sexual violence; Sexual abuse within the family; Adolescence; Meanings; Resilience.

\section{Introdução}

Este trabalho baseia-se no estudo Resiliência e Violência Sexual: um estudo sobre adolescentes vitimizadas por abuso sexual intrafamiliar (MARANHÃO, 2008), desenvolvido sob a forma de monografia, no qual se investigou o processo de construção de resiliência em adolescentes vitimizadas por abuso sexual no contexto familiar.

A resiliência é caracterizada como a superação de situações adversas, configurandose como algo processual, promovida pela interação de fatores de proteção pessoais e coletivos, em determinado contexto de risco ou vulnerabilidade social. Essa é uma categoria recente nas Ciências Humanas e, principalmente, nas Ciências Sociais. Surge em meados da década de 1930, segundo Koller, Morais e Santos (2009), articulada à Psicologia Positiva, que busca entender a constituição do sujeito a partir de fatores positivos, saindo do paradigma da situação de risco, doenças ou problemas sociais sem, no entanto, negálos, mas, entendendo-os como integrantes das vivências dos sujeitos.

A violência tem sido um tema de debate atual, ora focando nas medidas de contenção de seus agentes, ora nas possibilidades de construção de medidas para prevenila. Tal fenômeno social pode ocorrer de diversas formas - física, institucional, psicológica, sexual -, e seu reconhecimento depende da conjuntura social e valores éticos e políticos de cada sociedade. Conceitua-se por violência, neste trabalho, uma relação desigual entre vítima e agressor capaz de produzir danos físicos, psicológicos e sociais no sujeito a quem é investida, sendo permeada por características históricas e culturais de determinada sociedade, que se distingue do poder devido a seu caráter arbitrário (MARANHÃO, 2008).

O abuso sexual intrafamiliar contra adolescentes é uma das tipologias da violência sexual que envolve tanto a agressão física quanto a psicológica, anulando a vontade do 
outro de exercer sua sexualidade de forma livre e desconsiderando os adolescentes como sujeitos em condição peculiar de desenvolvimento. Assim, requer analisar o abuso sexual a partir de um olhar histórico, social, cultural e econômico, a fim de que sejam contempladas suas dimensões e impactos na sociedade e na vida do sujeito vitimizado. 0 foco deste artigo será a discussão sobre os significados do abuso sexual a partir da percepção de adolescentes que vivenciaram tal situação.

\section{Percursos da pesquisa}

A pesquisa ora apresentada é de caráter qualitativo e tem como referencial teóricometodológico a Teoria Histórico-Cultural. Utilizou-se também para a coleta e análise dos dados técnicas inspiradas na Antropologia, das quais: a observação participante e a descrição dos fenômenos por meio do diário de campo. Dada à singularidade da temática desta pesquisa, optou-se pela observação para o registro das "situações" presenciadas pelas pesquisadoras no lócus de acompanhamento psicossocial das adolescentes, o Centro de Referência Especializado de Assistência Social (CREAS Regional de Fortaleza) ${ }^{1}$, como espaço de apreensão dos significados da violência.

Para a apreensão do significado das vivências das adolescentes foi realizada entrevista aberta semiestruturada como instrumento que possibilita a aproximação da percepção dos sujeitos sobre sua vivência a partir de sua fala e, na qual, observamos seu modo de interagir, conhecendo aspectos de sua vivência. A análise dos dados ocorreu a partir dos elementos obtidos na observação, na entrevista e análise de documentos institucionais.

O critério de escolha das entrevistadas foi realizado a partir da identificação dos casos de abuso sexual intrafamiliar notificados e atendidos no segundo semestre de 2010 e nos três primeiros meses do ano de 2011, continuando até o mês de julho em acompanhamento pela equipe técnica do CREAS Regional de Fortaleza ${ }^{2}$. Foram escolhidas quatro adolescentes do sexo feminino entre 12 e 16 anos de idade que, de acordo com a

\footnotetext{
${ }^{1}$ O Centro de Referência Especializado de Assistência Social é uma das instituições componentes da Política Nacional de Assistência Social cujo objetivo é oferecer atendimento psicossocial a sujeitos com vínculos familiares fragilizados ou inexistentes devido à situação de vulnerabilidade, risco e violência, a fim de possibilitar a reinserção social desses sujeitos e a garantia de seus direitos (BRASIL, 2004).

${ }^{2}$ Excetuando uma delas que iniciou seus atendimentos no ano de 2008, continuando até o ano de 2010.
} 
avaliação do profissional de psicologia que as acompanhava, estavam em condições emocionais e psicológicas de dialogar sobre sua vivência. A prevalência do gênero feminino vai ao encontro de dados estatísticos da violência sexual na própria instituição de referência para a pesquisa, onde predomina a menina-mulher como vítima, mesmo não isentando a vitimização de meninos e adolescentes do sexo masculino.

A autorização das adolescentes e de seus responsáveis foi realizada por meio de Termo de Consentimento Livre e Esclarecido (TCLE), em consonância com a Resolução 196/96 (BRASIL, 1996) ${ }^{3}$. Optou-se por dois termos, um para a assinatura da pessoa responsável e outro para a adolescente, por considerá-la como sujeito participativo e sua concordância como demonstração de sua liberdade, e autorização em falar sobre sua vivência. Além do mais, foram adotados codinomes para identificar as adolescentes, haja vista a garantia do sigilo e da dimensão ética na pesquisa. Assim, as participantes da pesquisa são Rosa, Jasmim, Dália e Lírio. Para esta escolha utilizamos como referência a simbologia da Campanha Nacional de Combate à Violência Sexual contra Crianças e Adolescentes, a Flor Amarela. Este símbolo foi escolhido a partir de uma discussão nacional dos Fóruns de Enfrentamento à Violência Sexual contra Crianças e Adolescentes junto ao Comitê Nacional de mesma temática, a fim de estabelecer uma marca única de proteção, prevenção e combate à violência sexual. Reproduziremos, aqui, um breve perfil das adolescentes entrevistadas.

A primeira entrevista foi realizada com a adolescente Rosa, de 15 anos, que vivenciou uma situação de abuso sexual intrafamiliar por parte de seu genitor. A escolha do nome Rosa, que significa amizade, foi criada devido à característica ressaltada pela adolescente ao relatar sobre si mesma, "ah, a maioria das minhas amigas né dizem que eu sou legal né". A situação de abuso ocorreu desde os 11 anos de idade da adolescente, cessando quando esta tinha 12 anos. O acompanhamento psicossocial iniciou-se em 2008 e finalizou em 2010.

A segunda história de vida é a de Jasmim, de 12 anos, que significa graça ou beleza delicada. O nome foi escolhido tanto pela personalidade da adolescente, que se define "eu sou muito brincalhona", quanto pelo seu aspecto físico, pois apesar de adolescente, ainda apresenta feições infantis. A adolescente vivenciou uma situação de abuso sexual

\footnotetext{
${ }^{3}$ Dispõe acerca de diretrizes e normas regulamentadoras de pesquisas envolvendo seres humanos.
} 
intrafamiliar, cujo agressor foi o esposo de sua tia materna. A situação de abuso ocorreu no início do ano de 2010, aos 10 anos de idade da adolescente, durando entre 4 a 5 meses e cessando quando esta ainda estava com a mesma idade. $\mathrm{O}$ acompanhamento psicossocial iniciou-se em 2010 e finalizou em 2011.

A terceira adolescente tem 16 anos de idade e vivenciou uma situação de abuso sexual intrafamiliar por parte de seu padrasto. Ela será chamada de Dália, que significa delicadeza. Apesar de se caracterizar como "eu tenho muita paciência" e tentar demonstrar uma personalidade forte, pela análise da sua entrevista e comportamento, percebemos uma fragilidade e busca de fortalecimento de sua identidade. A situação de abuso ocorreu desde os 9 anos de idade da adolescente, cessando quando esta tinha 15 anos. 0 acompanhamento psicossocial iniciou-se em 2010 e ainda está em andamento.

Por fim, a quarta adolescente entrevistada será chamada de Lírio, por sua característica meiga e doce, peculiares a esta flor. A adolescente tem 12 anos e, desde que nasceu, morava com sua genitora, seu genitor e mais 2 irmãos. Com o divórcio dos pais, a genitora construiu um novo relacionamento afetivo. A situação de abuso ocorreu na residência materna, sendo praticada pelo padrasto quando Lírio tinha 10 anos de idade. Em um primeiro momento, houve a separação da genitora do suposto agressor, no entanto, com o nascimento de um filho de ambos, houve o retorno daquele para o convívio com a adolescente, ocorrendo nova tentativa de abuso sexual, desencadeando a ida de Lírio para a residência paterna. O acompanhamento psicossocial iniciou e finalizou em 2011.

\section{Adolescência e teoria histórico-cultural}

A adolescência, fase da vida caracterizada como momento de transformação e amadurecimento do corpo infantil para o corpo adulto, define-se como um período psicossociológico (SANTOS; XAVIER; NUNES, 2008) no que tange à descoberta e inserção em novos espaços sociais dos adolescentes.

Entende-se a adolescência como um conceito que envolve aspectos biológicos, culturais e históricos, sendo caracterizada e significada de acordo com a sociedade em que está inserida, inclusive, "por estereótipos, momentos históricos, referências diversificadas e situações de classe, gênero, raça, entre outras" (UNESCO, 2004, p. 27). No entanto, a 
delimitação desse período da vida é algo recente, haja vista ser apenas no final do século XIX e início do século XX que ocorre a diferenciação entre infância e idade adulta e, posteriormente, a adolescência (PALÁCIOS; OLIVA, 2004). Essa distinção ocorre por meio da reforma moralista e o surgimento da escola no final do século XVII, como meio de educar a criança, que foram dando contorno do que viria a ser a construção de um significado de infância e que tiveram duas consequências: a escolarização e a delimitação da família nuclear burguesa (ÀRIES, 2006).

Posteriormente, a complexificação da escolarização com a distinção de idades e o aumento do tempo de preparação para o mundo do trabalho, contribuiu para o estabelecimento de um novo estado social, a adolescência, como um produto do século XX (PALÁCIOS; OLIVA, 2004), haja vista nos séculos anteriores não existir uma cultura adolescente e nem a adolescência ser considerada uma fase particular do desenvolvimento. Deste modo, as mudanças na organização social do trabalho favorecem o surgimento na cultura ocidental de um novo grupo que desenvolve seus próprios hábitos e maneiras, que enfrenta problemas peculiares.

Ressalta-se que, em uma mesma cultura, podemos encontrar diversas formas de se adolescer, o que nos faz pensar em adolescências para distinguir esses grupos tão heterogêneos entre si. De acordo com a Psicologia Histórico Cultural, o sujeito a partir das suas vivências, constrói a si mesmo e ao mundo ao seu redor, por meio de sentidos que atribui ao contexto social e suas vivências, resultado de um mútuo processo (VYGOTSKI, 1995).

De acordo com Vygotski (1995), a construção subjetiva do sujeito ocorre pela internalização de $\operatorname{signos}^{4}$ por meio dos processos psíquicos superiores, entre eles a linguagem e o pensamento. A linguagem é o instrumento de mediação no qual o sujeito internaliza os signos/significados e os modifica internamente dando um sentido próprio. Com essa compreensão, é possível refletir sobre os fatores de vulnerabilidade e violência vivenciados por alguns adolescentes e de como esses eventos influem em seu desenvolvimento psicossocial e afetivo e na sua interpretação e relação com o mundo.

\footnotetext{
${ }^{4}$ Os signos, entendidos como instrumentos convencionais de natureza social, são os meios de contato do indivíduo com o mundo exterior e também consigo mesmo e com a própria consciência. São palavras e valores sociais construídos pela cultura, ou seja, tudo aquilo que possui um significado e se remete a algo situado fora de si mesmo (AGUIAR, 2001).
} 
Segundo Saffioti (1989), o reconhecimento da violência contra adolescentes tornase difícil devido a uma associação de sua imagem com o desejo de independência, agressividade, contestação, com poder de defesa, se agredido, ocorrendo uma descrença sobre a existência de violência ou, quando real, como algo merecido pelas atitudes do adolescente. No caso específico da violência sexual, ela ocorre em diversas classes sociais, tendo se estabelecido como fenômeno de difícil enfrentamento, devido à proximidade entre vitimizados e agressores, tendo a presença maçante do público feminino como a principal vítima.

Geralmente, iniciando na infância, os efeitos psicossociais do abuso sexual pode perdurar durante a adolescência e fase adulta, seja nas dificuldades de construção de relacionamentos afetivos, seja na submissão a outras situações de violência por parte dos companheiros, no caso das mulheres, baixa-estima, prostituição, uso abusivo de álcool e drogas ilícitas e até mesmo a reprodução da violência sexual, na qual as vítimas podem repetir o ciclo de violência (SAFFIOTI, 1989; SANTOS, XAVIER, NUNES, 2008).

Assim, para que se possa compreender a relação entre adolescência e violência sexual, é preciso reconhecer a história do sujeito, as formas como tem se estabelecido as relações familiares e as circunstâncias que as produzem.

\section{Contextualizando a vitimização sexual de adolescentes na família}

A violência caracteriza-se como qualquer tipo ou grau de dano contra a integridade física-psicossocial de outrem, produzindo sofrimento e dor (AGÊNCIA NACIONAL DOS DIREITOS DA INFÂNCIA - ANDI, 2008). Corrobora para esta definição o pensamento de Azevedo e Guerra (1989, p. 42), ao tratar sobre a violência contra crianças e adolescentes considerando-a como "todo ato ou omissão cometido por pais, parentes, responsáveis, outros indivíduos, instituições públicas ou privadas capazes de causar dor ou dano físico, sexual e/ou psicológico ao vitimizado".

A violência, além de desqualificar fisicamente o sujeito a quem é direcionada, comporta uma carga social de desvalorização da autoimagem de sua vítima. Quando exercida contra a criança e o adolescente, torna-se mais grave, devido à peculiaridade desses sujeitos estarem em processo de desenvolvimento e socialização, gerando danos na sua formação psíquica e social. 
No que se relaciona à violência sexual contra a criança e o adolescente, esta passa a ser reconhecida como fenômeno endêmico na sociedade brasileira, exigindo políticas públicas para o seu enfrentamento e a necessidade de proporcionar a estes sujeitos proteção integral, com o objetivo de que a criança e o adolescente atinjam um desenvolvimento saudável. Conforme os artigos $4^{\circ}$ e $5^{\circ}$ do Estatuto da Criança e do Adolescente que estabelecem o dever da família, da sociedade e do poder público de assegurar com absoluta prioridade a efetivação dos direitos desses sujeitos, bem como protegê-los de qualquer forma de negligência, discriminação, exploração, violência, crueldade e opressão (BRASIL, 1990).

Contudo, apesar do avanço legal pertinente à legislação infantojuvenil e com a mudança do Código Penal Brasileiro no ano de 2009, substituindo a titulação dos crimes sexuais contra a moral da sociedade para crimes contra a dignidade sexual, discernindo a liberdade dos sujeitos sobre seu próprio corpo, e de que a violação deste princípio fere seus direitos, ainda permanecem diversas formas de violação.

No ano de 2010 foram registradas no CREAS Regional de Fortaleza 3.220 denúncias de violência contra crianças e adolescentes, dentre as quais 425 foram de violência sexual e destas 327 tipificações de abuso sexual. Entre os vitimizados encontramos nos meses de julho a dezembro de 2010, 36 meninos e 118 meninas, sendo que destes, na sua grande maioria, tinham entre 7 e 14 anos, composto de 23 meninos e 67 meninas nessa faixa etária. Referente ao ano de 2011 encontramos até o mês de julho 2.205 denúncias, das quais 922 são de violência sexual, sendo 239 de abuso sexual. Prevalecendo também a faixa etária de 7 a 14 anos, com 22 meninos e 101 meninas.

Percebemos, pela análise desses dados, uma primazia pelos sujeitos do sexo feminino no período da infância e pré-adolescência. Saffioti (1989) aponta que a preferência por crianças, em casos de abuso sexual, apresenta-se com a afirmação de poder e não como resultado de uma pulsão sexual e reprimível, reforçando o aspecto cultural e não biológico do abuso sexual. Inclui-se também o aspecto geracional demarcando o adultocentrismo presente nessas relações. Por haver uma cultura do controle do sujeito infantil este se torna o alvo mais vulnerável, perdurando a situação abusiva durante a adolescência. 
Utilizamos, ao nos referirmos às vítimas de violência sexual, o conceito de vitimização proposto por Saffioti (1989) caracterizada por ocorrer no plano das relações sociais, fazendo-se presente em qualquer classe social, delineada por uma relação de hierarquia entre vitimizado e agressor, acompanhada da "síndrome do pequeno poder" (SAFFIOTI, 1989, p. 17), no qual, por não deter um poder maior, o agressor extrapola de sua autoridade e passa a violentar pessoas que hierarquicamente dependem dele. Trata-se de um fenômeno que tem na mulher-criança a maior vítima, o que se relaciona a uma raiz no padrão falocrático de relações sociais de gênero, constituindo a violência sexual uma das formas de expressão desta síndrome (SAFFIOTI, 1989).

Por ser social, tal síndrome é produzida pela estrutura social, não ocorrendo somente por atributos pessoais negativos do agressor. É nesse âmbito que traremos o debate sobre a violência sexual contra adolescentes como uma prática social articulada a um modo de relações de determinada sociedade, comportando uma carga cultural e histórica. De tal modo, neste trabalho utilizaremos como definição para a violência, uma relação desigual entre vítima e agressor, capaz de produzir danos físicos, psicológicos e sociais no sujeito a quem é investida. Distinguindo-se do poder devido a seu caráter arbitrário.

A violência na família, particularmente a violência sexual, é uma distorção de um poder social e simbólico, fornecido aos pais para os cuidados de seus filhos, que neste caso passa a caracterizar-se como violência, uma vez que deixa suas funções de cuidados e orientação, tornando-se uma relação de abuso.

A violência sexual envolve também a questão de gênero, em que a diferenciação entre homens e mulheres é utilizada como instrumento de dominação e violência. Sendo geralmente a figura masculina o principal agressor, no qual o homem (pai/padrasto), enquanto provedor da família e de autoridade, ordena sobre sua vida, de sua esposa e filhos, compondo relações de submissão e agressão e, ao mesmo tempo, de cumplicidade dos familiares em não desafiar tal poder.

Segundo Molas (2009), o poder familiar tem sua origem na produção de sujeitos sociais no âmbito doméstico, em que a esposa se torna responsável pelo controle e disciplinamento das crianças, e ao homem é delegada a implantação da norma à mulher e aos filhos, como representante do Estado na família. 
Nos casos em que o agressor se encontra em meio familiar, a família, instituição social simbolizada como local de proteção e segurança, tem seus referenciais distorcidos, tanto no estabelecimento dos papéis familiares e na formação de identidade do sujeito como na socialização de laços afetivos e de confiança com os pais, apresentando-se nessas situações como um lugar de risco e vulnerabilidade. A saída de tal situação é dificultada, devido a uma tradição em idealizar a família como instituição social intocável e pela crença desse espaço como meio invulnerável e de proteção.

A violência sexual é subdividida, segundo a Cartilha de Enfrentamento à Violência Sexual de Crianças e Adolescentes do Centro de Defesa da Criança e do Adolescente (CEDECA, 2007), para a melhor compreensão e intervenção em: exploração sexual comercial e abuso sexual. É considerada exploração sexual comercial a utilização do corpo do outro visando o lucro, mediante remuneração em dinheiro, roupas, comida ou outra forma de pagamento. Nesse caso, a criança e o adolescente são vistos como vítimas, pois, normalmente, há um adulto se beneficiando dessa pessoa, sendo o aliciador membro da família, proprietários de hotéis e bares etc. Enquadra-se aí também o turismo sexual e a pornografia.

Já o abuso sexual ocorre quando um adulto ou adolescente mais velho que a criança busca uma aproximação para obter prazer sexual, fazendo uso de artifícios diversos como promessas, ameaças, força física e drogas. O abuso sexual ainda se diferencia em intrafamiliar, quando ocorre no meio familiar, facilitado pelas relações de poder e confiança entre o agressor e a vítima, ou extrafamiliar, quando é praticado por terceiros de quem a vítima gosta ou confia (vizinhos, professores etc.). Ocorre por meio de carícias, conversas de cunho erótico, para despertar interesse ou chocar, atentado violento ao pudor, estupro, voyeurismo, ocorrendo com ou sem penetração e com ou sem violência física.

O abuso sexual intrafamiliar tem sido de difícil enfrentamento, visto seu caráter sigiloso, uma vez que ocorre dentro do âmbito privado da família, sustentados, dessa forma, pelos vínculos e valores familiares que impõem ao vitimizado a manutenção da família, ou a imagem que dela se tem, impedindo à vítima de exercer sua liberdade sexual (MOLAS, 2009); e desconsiderando a peculiaridade de crianças e adolescentes como sujeitos em desenvolvimento. 


\section{Sentidos da violência sexual para as adolescentes vitimizadas}

Neste tópico, discutiremos acerca da percepção das adolescentes sobre si mesmas, como se sentem ao falar da violência sexual, o que pensavam em fazer nessa situação, como foi a revelação, qual o sentimento diante da descoberta/revelação, se elas enxergam alguma solução para a violência sexual sofrida e suposições sobre o motivo desse fenômeno ter ocorrido.

A apreensão sobre a percepção das adolescentes sobre si mesmas ocorreu por meio de perguntas sobre quais qualidades elas atribuíam a si mesmas, possibilitando uma aproximação sobre a autoimagem; bem como possíveis influências no modo do sujeito se ver pós-abuso sexual. Deste modo, a qualidade escolhida por cada adolescente diz mais sobre ela, contribuindo para a compreensão de como o sujeito relaciona-se com o meio externo e lida com as suas experiências.

Encontramos nas definições, qualidades descritas a partir da percepção de atributos que outros enxergam como bons, tais como:

Ah, a maioria das minhas amigas né dizem que eu só legal né, mas às vezes eu sou chata quando eu tô na tpm eu sou muito chata, quando elas quê algum apoio eu dô, dô apoio a elas, essas coisas (Rosa).

Algumas discordâncias entre o que os outros dizem e o que é percebido pelo sujeito estão relacionados à dificuldade em atribuir-se uma qualidade devido à história de vida, dificultando o pensar sobre si mesmo e ainda atribuir-se percepções positivas.

Outras definições de qualidade foram referidas pelo modo como agem em seu cotidiano como: "eu tenho muita paciência" (Dália). Essa característica é confirmada no trecho:

Porque eu já aguentei tanta coisa. (risos) Só que às vezes a pessoa não aguenta mais, aí a gente explode, (risos), eu aguento tanta coisa, aí depois quando é na hora aí sai tudo de uma vez (Dália).

Essa atitude da adolescente demonstra certa passividade diante de sua vida e espera por algo que possa mudá-la. Durante a entrevista, foi recorrente o riso ao relatar situações de conflito com familiares, o que demonstra uma incongruência do sentimento verbalizado 
para o sentimento expresso pelo corpo e suas feições, pois percebemos uma angústia da adolescente, disfarçada pelo riso, como tentativa de não dar importância a acontecimentos que marcaram sua vida. Tal comportamento reflete tanto a personalidade da adolescente quanto o contexto social em que estava inserida, no qual a genitora detinha o controle de sua vida, inclusive para definir seus sentimentos, causando uma relação de dependência.

Ressalta-se, também, que cada característica contribui para o modo como as adolescentes lidam com as adversidades, e de como buscam outra forma de interação social.

$$
\begin{aligned}
& \text { Sou legal, sou mais ou menos simpática. } \\
& \text { O que mais, eu sou muito brincalhona (Jasmim). } \\
& \text { Eu sou alegre (demonstrando timidez). } \\
& \text { Eu gosto muito de fazer amizade. Gosto muito (Lírio). }
\end{aligned}
$$

Neste trecho, percebemos uma autoimagem positiva de si mesmas pelas adolescentes. O bom humor e a capacidade de sentir-se feliz mesmo depois de viver uma situação de violência demonstram um fator protetivo do sujeito em ponderar essa experiência como uma das vivências de sua história, sem deixar sua personalidade totalmente frágil, e de distinguir também o que lhe desagrada e se proteger contra isso.

Eu não tô mais entrando em contato com ele (agressor), voltei às brincadeiras, tento não ficar mais pensando naquilo, se é pra mim (pausa), se é pra eu ficar parada pensando eu prefiro ler alguma coisa ou então conversar, mas nunca é fico pensando né? (Jasmim).

Em relação ao que conheciam sobre a violência sexual, percebemos que as adolescentes pouco ou nada entendiam da situação vivenciada, apenas associavam a uma sensação de desconforto. Inclusive, ao serem arguidas sobre como se sentiam ao falar do assunto, foi comum um quadro de timidez por parte das adolescentes com 12 anos, no entanto, não houve resistência em falar sobre o abuso sexual.

Percebemos que as adolescentes de 15 e 16 anos de idade conseguiram elaborar melhor a sua fala, e tiveram uma abertura para falar sobre si, inclusive relatando quase como uma "novela" a trajetória da relação abusiva e do quanto essa situação lhe causava angústias e incômodos. 
Uma das explicações para além do amadurecimento biológico e cognitivo é que essas duas adolescentes tinham um período maior de acompanhamento psicossocial, o que contribui para a sua organização no âmbito afetivo, social e psicológico. O que pudemos perceber também foi um amadurecimento em relatar suas vivências como algo doloroso, mas que elas estavam aprendendo a lidar, diferente do padrão seguido à época da situação abusiva em que houve dificuldades em revelar a violência. Como mencionado nos trechos a seguir,

Agora eu já me sinto mais um pouquinho aliviada, mas antes eu tinha um pouquinho de receio de falar (Jasmim).

Assim eu me sinto bem porque eu era... Eu era presa com esses negócios. Assim eu não conseguia dormir direito pensando..., agora não, eu sou livre eu falo com, eu falo com qualquer pessoa, menos com as minhas amigas, eu não falo isso de jeito nenhum (Rosa).

Quando eu falava nos primeiros meses eu chorava, mas agora eu me sinto super bem (Dália).

O que denota ser um fator de resiliência, ao se trabalhar a fala sobre as vivências do sujeito, mesmo aquelas negativas, mas que com um atendimento qualificado podem tornar-se algo da experiência que fortaleça o sujeito, tornando-se um meio terapêutico de alívio e descarga dos sentimentos.

Em relação à revelação, compreendemos que não existe uma definição de momento, formas ou idade para a denúncia do abuso sexual por parte das vítimas. O que se tem percebido é que, geralmente, a violência inicia na infância e, quando a criança e o adolescente não encontram suporte na família, a fim de ter a confiança e apoio dos adultos responsáveis por eles, a denúncia pode vir a não existir ou quando ocorre não ter prosseguimento. No caso do abuso sexual intrafamiliar, são diversos os fatores que favorecerão ou não sua revelação e denúncia, interferidos, frequentemente, pelo medo ou negligência da família, que impede que a violência sexual seja reconhecida em seu meio.

Geralmente, há um sentimento de insegurança e medo por parte do adolescente em procurar ajuda dentro e fora da família, e cada sujeito demonstra uma forma de reação para o abuso sexual sofrido, desde a baixa autoestima, comportamento mais agressivo ou introvertido, como demonstram os relatos a seguir. 
Ele me ameaçava [...], eu nunca dizia pra ninguém, eu chorava, eu era muito revoltada mesmo, eu era revoltadíssima mesmo, agressiva. Todo mundo que chegava perto, um homem quando chegava perto de mim e alisasse no meu rosto já era um crime pra mim (Rosa).

Quando ele entrou lá em casa e, ele entrou e, já me proibiu já de andar lá fora, é de ficar em casa fazendo as coisas e tal. Aí nasceu minha irmã aí eu tive que começar a cuidar da minha irmã. Aí tipo, eu parei de viver, eu era completamente presa lá em casa, não vivia com ninguém, todo mundo me achava estranha, me dizia que eu era muito feia, muito fechada. Nem o pessoal da minha família mesmo, eu era muito fechada, é, eu parei de falar com meus vizinhos, não conhecia mais ninguém, eu era completamente, nem ia pro meio da rua, nem, nem isso eu andava no meio da rua (Dália).

Você fica com vontade de falar, mas ao mesmo tempo você tem medo de falar entendeu? Aí aquilo ali já tava é, já enchendo um pouquinho a paciência já tava ficando chateada, com raiva porque queria falar e não podia (Jasmim).

Nos discursos analisados, um dos significados do que a violência causava nos sujeitos vitimizados consistia em algo que incidia na consciência das adolescentes, mas que elas não conseguiam elaborar. Mesmo que o sujeito vitimizado perceba em suas relações a presença do abuso, coexistem sentimentos de culpa, vergonha, o medo da revelação e de sua não credibilidade, e, ao mesmo tempo, sentimentos de afeto e sujeição, em relação ao agressor, o que pode geralmente inviabilizar a denúncia.

Quando logo, quando aconteceu logo comigo eu queria contar pra minha madrasta, mas sempre ela dizia que era mentira minha, ela disse que eu mentia, que eu botava homem dento de casa, que eu namorava aí ninguém, ninguém acreditava em mim né? (Rosa).

[...] eu contei pra minha mãe duas vezes só que ela não acreditou muito. [...] ela me botou na frente dele pra mim dizer na cara dele, só que eu não tinha coragem, eu era criança, eu mal sei direito um negócio desse tamanho (Dália).

Eu contei pra minha madrinha. Aí a minha madrinha né, ficou calada, ela pediu pra manter segredo. Aí eu pedi pra ela falar pra minha mãe, ela não falou. [...] aí depois que eu contei pra minha mãe elas ficaram conversando, falou que eu tinha contado pra ela e tudo. [...] Eu cheguei a contar pra minha amiga [...] depois que eu contei pra minha mãe (Jasmim).

Assim, quando isso aconteceu eu [...] disse pra minha mãe e ele negando, dizendo que era mentira, só que era verdade, só que minha mãe não acreditou em mim (Lírio).

Diante do exposto, percebemos que existem outros fatores além das ameaças e do medo em relação ao agressor, que é a não credibilidade na fala do adolescente ou mesmo 
a indiferença dos adultos, os quais deveriam proteger a criança, dificultando mais ainda a revelação do abuso sexual logo no seu início. Nos trechos a seguir, percebemos a dificuldade de proteção de familiares, ainda permanecendo a crença na culpa da vítima, por seduzir seu agressor ou fantasiar a violência.

Não eu tinha falado, mas assim (madrasta) "eu acho que eu perdi minha virgindade" dizendo pra ela, que o nome dela é [...], "eu acho que perdi minha virgindade". Ela, "mentira tua, tu é muito mentirosa" ela sempre dizia isso, mas Deus é tão bom né que botou minha tia na minha vida e até hoje eu tô com ela (Rosa).

A presença de algum adulto que acredite na adolescente é fundamental para a construção de uma nova cultura de proteção e convívio familiar. Valorizando o cuidado e respeito entre os sujeitos e o reconhecimento dos direitos de suas crianças e adolescentes, assim como contribuindo para a (re)significação da violência e melhora na autoestima das adolescentes. Além de que a credibilidade na fala do adolescente é fundamental para o cerceamento da violência, uma vez que o abuso sexual é algo que ocorre no âmbito da intimidade, sendo o relato um dos meios de admitir a situação.

Ressalta-se também que, muitas vezes, tanto para o senso comum como para alguns profissionais, a sincronia da fala do sujeito vitimizado, com provas materiais como, por exemplo, o exame de corpo delito é exigido para dar veracidade à violência, o que limita a ocorrência do abuso sexual apenas à conjunção carnal e não a outras formas como ocorre, tais como: atos libidinosos, conversas de cunho erótico ou voyeurismo. Nesse sentido, fazse necessário profissionais capacitados para a escuta, inclusive o silêncio, como uma das formas de expressão da situação de violência, mas que ainda não foi elaborada pelo sujeito para que esse discurso seja o mais espontâneo, reconhecendo o amadurecimento e nível de fortalecimento do sujeito.

Deste modo, compreendemos a fala como um direito da criança e do adolescente em expressar o que lhe ocorreu a partir de sua concepção. Deve-se cuidar para que esse momento não deixe de ser um direito, para se tornar uma obrigação da pessoa que sofreu violência, pois é ele que deve ser protegido e não ser um mero objeto de prova da violência. Portanto, percebemos que para a revelação da situação abusiva coexistem diversos fatores que vão além da livre escolha do sujeito, mas dependem de um ambiente que ofereça o 
mínimo de segurança e credibilidade, para que este perceba a saída da situação de violência. Esse ambiente protetivo depende tanto da articulação entre a família, a comunidade e o Estado, como do modo que o sujeito o percebe e reconhece esses fatores de proteção. Essa segurança de poder contar com alguém e ser reconhecida como vitimizada possibilita também uma autoimagem valorizada de si mesmo, ao perceber que nesse momento, diante de sua condição de desenvolvimento e aprendizado, é ela que deve ser protegida, como descrito no trecho a seguir.

[...] aquilo ali já tava é, já enchendo um pouquinho a paciência, já tava ficando chateada, com raiva porque queria falar e não podia e, aí chegou uma hora que eu pensei se eu contar pra minha mãe eu acho que minha mãe não vai ficar com raiva de mim, acho que ela vai ficar do meu lado. Aí eu peguei e decidi contar (Jasmim).

Algo comum no discurso de Rosa, Jasmim e Dália, ao serem arguidas sobre o que elas entendiam por violência, foi que disseram não saber o que acontecia, mas diante do abuso sexual, passaram a associar informações televisivas e conversas de amigas ao conteúdo do abuso.

Peraí que eu, eu sei responder, o problema é achar as palavras é, isso é pank, porque provavelmente ele me deixou traumas e isso pra mim foi, muito assim, foi uma coisa que, eu não sabia que existia, ele fez comigo, eu não sabia que aquilo era errado, eu fiquei sabendo sabe que eu vi na televisão quando a Claúdia Leite se casou, ela disse que se casou virgem aí eu comecei a chorar "será que eu sou virgem, será que eu não sou virgem". Aí, aí eu sabe fiquei numa depressão horrível porque eu pensei por vários dias "será que eu sou virgem" e num sei quê, porque eu não sabia o que acontecia comigo [...] (Dália).

[...] aí sempre ele fez isso comigo me abusou, aí depois que eu vim descobrir que isso ali era errado passava no jornal. Aí eu peguei e vi e sabia que era errado, mas ele disse que se eu contasse pra alguém ele me matava e matava a pessoa que me ajudava né (Rosa).

Antes eu não sabia direito só via assim às vezes na televisão e não dava importância, mas depois que isso aconteceu comigo eu já ouvi falar outras histórias, já assisti na televisão casos e também o, uma menina lá na minha escola, ela já falou e tudo que aconteceu com ela aí, mas a mãe dela não correu atrás (Jasmim).

Diante dos relatos, podemos apreender como se dá o processo de descobrimento da relação abusiva, por meio da tentativa de interpretar e significar a sua vivência. No trecho a seguir, percebemos o caráter abjeto, desconhecido e, consequentemente, desnorteador 
do abuso sexual, pois era algo tão estranho da realidade vivenciada, que a adolescente não sabia o que tinha acontecido, não sabia dar um nome, uma vez que ela ainda não tinha o conhecimento sobre o exercício da sexualidade e discernimento de um adulto.

[...] ele fez uma briga pelo um quarto. Aí esse quarto é bem isolado sabe, isolado mesmo, lá no fundo da casa, aí esse quarto foi pra mim. Aí depois disso foi acontecendo, acontecendo uma coisa que eu não sabia o que era aquilo, eu tinha apenas 11 anos eu não sabia o que era aquilo (Rosa).

Percebemos que quanto mais próximas de formar um sentido para a relação de abuso, mais angustiante tornava-se a vivência com o agressor. Algumas das dúvidas e conflitos apresentados nos discursos das adolescentes foram: supor a perda da virgindade e se o tipo de relacionamento entre elas e os agressores era correto.

[...] eu tava dormindo, aí minha madrasta tava dormindo na sala (...) no oto dia eu tava sangrando né por causa, "ah meu Deus será que eu menstruei não". Aí eu peguei, aí escutei uma menina, uma colega minha dizendo que ela tinha perdido a virgindade acho que isso também que meu pai fez comigo né (Rosa).

É aconteceu, já vinha acontecendo assim acho que uns 5 ou 4 meses. Aí eu ficava calada, não contei pra minha mãe. Aí chegou um dia que veio me sufocou e eu decidi que ia falar pra minha mãe (Jasmim).

Realmente eu não sabia, eu sabia que aquilo é, era errado, porque eu sabia que eu não me sentia bem com aquilo. É, mais ao mesmo tempo eu não sabia o que era aquilo [...] (Dália).

Eu pensei a partir da frente, eu era, eu falava com ele e tudo, mas depois eu criei tipo um nojo dele. Eu não falo, não olho nem pra ele direito, passo por ele abaixo a cabeça (Lírio).

Percebemos que para que haja uma continuidade do abuso sexual há a necessidade do sigilo, do medo do sujeito vitimizado e da insegurança para revelar tal fenômeno, que se não é interpretado ou conhecido pelo sujeito que o vivencia torna-se inviável de ser revelado, conforme trechos a seguir:

[...] eu tinha muito medo por causa da minha mãe que ia sobrar pra mim (Dália).

Eu gostava muito de brincar, aí ultimamente eu não tava brincando, já ficava mais no meu canto pensativa, aí eu nunca fui muito de ficar pensativa assim direto entendeu? (Jasmim). 
Não eu não sabia o que era aquilo, uma vez ele tava, ele tava sentado perto de mim e ele disse "Rosa tu quer ver o papai preso", isso ele dizendo né? E eu "não pai quero não", eu morria de medo dele. Aí eu "não pai, quero não" e eu não sabia por que era que ele disse aquilo, aí eu perguntei a minha tia e minha tia disse que isso era um crime muito grande, um crime mesmo (Rosa).

Deste modo, a vítima fica impossibilitada de agir ou reagir, assim como de falar, passando a viver sob o medo e coação, dificultando a revelação da situação abusiva. O sujeito vive em

[...] estado de sítio, em que sua liberdade- enquanto autonomia pessoal- é inteiramente cerceada e da qual só se resgatará, via de regra, recuperando o poder da própria palavra, isto é, tornando pública a violência privada de que foi vítima (AZEVEDO; GUERRA, 1989, p. 35, destaque das autoras).

Sobre a vivência da situação de abuso sexual, compreendemos que ela deixa marcas no âmbito social e psicológico dos sujeitos que a vivenciam, expressando desde mudanças no comportamento como no âmbito afetivo do adolescente, o que contribui para uma baixa autoestima. Um dos resquícios da violência que afetou em especial a adolescente Dália foi um modo de agir mais distante dos outros sujeitos, como forma de proteção, "Olha hoje em dia [...] eu não sou muito de confiar em ninguém sabe [...] é eu analiso muito bem e não é tudo que eu conto sabe" (Dália).

Apesar de ser um recurso utilizado para que a adolescente se proteja, quando não discernido pode ser prejudicial à construção de novas relações sociais. Como no exemplo citado,

[...] Agora eu não deixo nenhum garoto me abraçar. Não deixo, eu não consigo, eles ficam frescando com a minha cara, quando vem passar a mão em mim eu digo sai, eu fico com raiva (Dália).

Necessitando, portanto, de um trabalho em relação ao estabelecimento de confiança e o prazer nas relações afetivas, como forma de satisfação e não de abuso.

[...] me dá nojo assim quando alguém vem me abraçar, é eu fico toda encolhida eu não retribuo abraço pra homem, mas em relação as minhas amigas eu retribuo, agora com garotos não. Eu tive problema quando eu namorei assim eu não, é, tinha muitos não, eu não era muito chegada a contar pras pessoas do meu namoro, poucas vezes a gente se beijava. Assim era uma vez perdida no dia, é no meu colégio. Foi ele que me ligou, aí poucas vezes, agora a gente tá se dando melhor, depois que a gente se separou que a gente tá se dando super bem, aí, é, é isso (Dália). 
Este trecho demonstra como em alguns casos de violência sexual pode haver um medo da intimidade, relacionado ao fato de ela possivelmente relembrar experiências traumáticas vivenciadas com um agressor que era próximo no plano afetivo (AZEVEDO; GUERRA, 1989). Inclusive, negando outra forma de relacionamento afetivo ou sexual, e perda ou diminuição de motivação sexual.

Sobre o sentimento que o abuso sexual causava encontramos:

É eu chorava mesmo, eu tinha depressão por causa disso, aí eu queria morrer (Dália).

Aí eu pensava assim em fugir pra bem longe. Aonde ele não pudesse mais me tocar. Não pudesse mais ver (Jasmim).

Assim, quando eu ia pro colégio eu pensava de não voltar mais pra casa, aí eu pensava assim "meu Deus pra onde eu vou". Quando dava seis horas que ele chegava do trabalho eu começava logo a me desesperar, quando chegava a hora de dormir, eu queria fugir, mas não conseguia porque ele me trancava dentro de casa, ele saia com a minha madrasta e me deixava sozinha com os meus irmão, sozinha dentro de casa aí... (Rosa).

O sentimento de fuga revela o desprazer da relação abusiva, e o quanto ele é incômodo e prejudicial para o desenvolvimento juvenil, bem como pela negação ao respeito da vivência de sua sexualidade de forma saudável e de acordo com o amadurecimento físico e psíquico do adolescente. Neste caso, encontramos a fuga como meio simbólico de encerrar a situação abusiva e, no caso específico de Dália, a morte como meio extremo e a solução mais rápida, por meio da anulação concreta do sujeito. O choro, muitas vezes, também foi utilizado como expressão da angústia, do que não pode ser dito, porque está sofrendo ameaça de morte concreta ou simbólica.

A partir dos acompanhamentos psicossociais realizados, percebemos que novos significados são reconstruídos pelas adolescentes, como no exemplo a seguir,

[...] é porque eu tava vivendo aquilo naquele momento né, mas agora que já passou, eu já tenho outra vida, eu não tenho mais nada a ver com aquilo ali, pra mim aquilo é passado e passado pra mim passou (Dália).

Tal trecho demonstra como foi o processo de conhecimento sobre si pela adolescente, possibilitando a superação de seus traumas, algo que não é realizado 
unicamente pelo sujeito, mas a partir das interações que ele constrói com o meio externo, por meio de acompanhamento e de novos ambientes e valores.

Cabe ressaltar que a ressignificação da situação de violência sexual, conforme proposto como promoção da resiliência, não é que o sujeito esqueça as situações adversas vivenciadas, pois isso seria mera ilusão. Porém, a intenção é fazer com que esse sujeito lide da melhor forma com tal situação, ressignificando-a como algo que fez parte de sua vivência e que, por mais difícil que seja, pode ser utilizado como fortalecimento para outras situações.

Em relação a algum episódio marcante, houve uma separação, tanto de fatos que remetiam ao abuso sexual e do uso arbitrário da autoridade de seus responsáveis como de momentos de empatia por parentes.

Um episódio foi quando eu fugi, saí de casa. Foi muito marcante pra mim. É foi dia 9 de abril (Dália).

Foi quando meu tio tentou é, como se diz, me assediar né. Lá na casa da minha vó (Jasmim).

Assim, porque no dia que eu fui fazer o exame pra saber se eu era virgem ou não o Conselho Tutelar me acompanhou e a minha tia também. Aí a minha tia tava sentada na cadeira e o doutor mandou eu tirar a roupa e vestir uma bata. Aí eu peguei e disse assim, "ai tia tá doendo", porque ele me mandava colocar muita força né, pra saber se eu era virgem ou não mesmo. Aí eu butava muita força, aí minha tia começou a chorar logo, ficou logo, entrou em desespero porque eu tava passando por aquilo (Rosa).

É com a minha irmã que ela que mora com a minha mãe, aí eu gosto muito dela eu acho uma coisa muito boa, na verdade eu lembro coisas boas, muito boa.

Ela tem 8 anos, ela é a pessoa que eu sou mais apegada (Lírio).

Deste modo, inferimos que a percepção de que se é protegida na família, mesmo numa situação dolorosa como no trecho relatado por Rosa, propicia um sentimento de empatia e a construção de um novo vínculo e uma nova cultura de cuidado e respeito para as adolescentes. Ainda na análise das histórias de vida, percebemos que os amigos também aparecem como um dos meios para a saída da relação abusiva e na construção de um vínculo de confiança.

Eu tinha contado pra minha amiga, mas eu tinha treze anos sabe? [...] eu pedi segredo total, [...] eu confiava muito nela (Dália). 
Eu cheguei a contar pra minha amiga Carol depois que eu contei pra minha mãe (Jasmim).

Nesse caso, as adolescentes utilizam desse recurso como uma forma de expressar seus sentimentos. No entanto, não conseguem dar um sentido de proteção, pois acaba permanecendo o sigilo e a não notificação da situação de violência sexual.

Em relação a alguma suposição para a ocorrência do abuso sexual, obtivemos como resposta,

Eu não sei por que, que aconteceu aquilo comigo, sei lá uma coisa assim estranha porque ele tinha a mulher dele, mas vinha atrás de mim né, até bebo, drogado, ele vinha atrás de mim. Até bom mesmo ele vinha atrás de mim e eu sempre perguntava por que e ele nunca me dizia. Aí eu disse pra ele que eu ia contar pra alguma pessoa aí ele disse, "pois diz que eu te mato". Aí ele é cheio de tatuagens, chera pó essas coisas, aí eu morria de medo dele (Rosa).

Por causa da imprudência da minha mãe e, porque eu não tinha noção do que era também, eu é, andava de camisola em casa, de toalha sabe, só que isso eu não fazia ideia de que poderia causar esse tipo de coisa, [...] e aquilo foi abrindo os meus olhos assim sabe é o que realmente se passou, porque pra mim eu não tinha feito nada né. Aí a minha mãe também por causa disso que ela me deixava sozinha à noite, sozinha quando ela tava trabalhando [...] aí ele ia pra casa, de 5 às 9 da noite também a gente ficava sozinho lá, isso foi muita imprudência dela. Aí ele dizia que ia dormir e não ia, aí é meu quarto tinha chave né, eu trancava só que no quarto dela tinha outra chave que abria o meu quarto, eu, eu já peguei ele entrando no meu quarto enquanto eu tava dormindo, só que eu tava inventando né. É com a minha irmã no braço, eu não me esqueço essa cena, com a minha irmã no braço dele e ele levantou o meu vestido. Aí, é isso (Dália).

Percebemos que as adolescentes conseguem discernir entre a sua condição de vitimizado e não como promotora da situação, caracterizando o significado da arbitrariedade do abuso sexual como algo prejudicial ao seu desenvolvimento.

Ainda sobre o agressor, encontramos,

[...] eu sempre chorava quando eu via ele, eu ficava branca [...] eu chorava, eu era muito revoltada mesmo, eu era revoltadíssima mesmo, agressiva todo mundo que chegava perto (Rosa).

Eu morava na casa da minha bisavó e de vez em quando ele dizia que a minha prima queria brincar comigo, ai eu ia pra casa dele né, que eu queria brincar com a minha prima, aí sempre que eu ia pra lá ele tentava. Aí eu sempre queria é fugir né, não deixava, mas toda vida que ele tentou eu ia e tentava sair de lá (Jasmim).

Que eu não gosto de dizer.

É do meu padrasto (Lírio). 
Nestes relatos apreendemos distintas maneiras de se relacionar com a figura do agressor, desde um sentimento de medo pelo que este representa, ou agir de forma agressiva como forma de expressar a aflição que o agressor causa, ou ainda a fuga como meio de libertar-se da violência; inclusive a não menção do fato, como instrumento de afastamento da situação abusiva. Ainda sobre uma forma de cercear a violência sexual obtivemos,

[...] Que eu não queria mais me encontrar com ele. Eu não queria assim, é como é que se diz ser preso, ficar na cadeia, eu não queria porque minha prima ainda é pequena e eu acho que ela vai sentir muito aquilo, aí eu não queria, mas se decidirem isso eu... (Jasmim).

Só que eu queria que ele saísse lá de casa. Assim eu não acho certo eles ficarem juntos depois do que ele fez (Lírio).

Deste modo, as apreensões acerca do agressor, demonstram que o seu distanciamento possibilita a ressignificação do ambiente familiar e a superação do medo ou angústia antes vivenciadas, sendo esse distanciamento uma das soluções que as adolescentes enxergavam para a violência sexual. Tais ponderações nos possibilitam refletir sobre a responsabilização do agressor não apenas como necessidade de punição na sua forma mais direta com a sua prisão -, mas como instrumento de garantia do bemestar a partir do afastamento do convívio do adolescente, aliado a um atendimento psicossocial que forneça meios de fortalecimento para a vítima.

\section{Considerações finais}

Percebemos nesta pesquisa, pela análise dos resultados, que o perfil dos vitimizados tem a primazia do gênero feminino no período da infância e pré-adolescência, e que os agressores se constituíram em homens adultos distinguidos nas funções familiares de padrasto, pai e tio, demarcando a composição da representação vítima-agressor articulada à questão de gênero como um dos desencadeadores da relação abusiva.

Na compreensão do abuso sexual juvenil, há que considerar também a problemática da geração, no qual as diferenças entre os distintos períodos da vida humana, infância, adolescência, adulto e velhice são tomadas hierarquicamente para o não reconhecimento do outro; geralmente tendo a dominância da figura masculina adulta sobre a criança e o 
adolescente, a mulher e o idoso. No caso de crianças e adolescentes, tal posicionamento advém do adultocentrismo que marca o não reconhecimento daqueles como sujeitos de direitos, tornando-os meros objetos das vontades dos adultos, inclusive para ultrapassar limites sociais estabelecidos como o incesto, violência física, agressões verbais etc.

Ressalta-se que a situação de abuso sexual, além de desconfigurar as funções familiares, fragilizando-as, é permeada por antagonismos, em que o vitimizado vive um dilema de amor/ódio, que o impossibilita, muitas vezes, de sair da situação de opressão. Neste sentido, a análise ou trabalhos com pessoas vítimas de violência têm sido fundamentais para a compreensão dos processos que possibilitam a ressignificação da vivência, a construção de perspectivas quanto ao futuro e o estabelecimento de relações com outros sujeitos, a partir de recursos pessoais e coletivos que favoreçam a mudança.

Ademais, os estudos que tratam sobre a resiliência em situações adversas, como a que tratamos neste artigo, têm problematizado não só a violência ou situação de risco, mas busca dar visibilidade às potencialidades e capacidades dos sujeitos diante dessas situações, por meio da análise do tecido social, as ações e interações do sujeito diante das adversidades e os recursos pessoais e coletivos que utiliza para se reorganizar. Possibilitando, dessa forma, um olhar diferenciado sobre os problemas sociais a partir da perspectiva do sujeito, tendo como norte a proteção e prevenção de violações de direitos.

O acompanhamento psicossocial mostrou-se necessário como espaço de mediação a partir da relação com profissionais, assistentes sociais, psicólogos, entre outros que podem compreender e acolher a situação, orientando percursos para lidar com o fenômeno da violência sexual por meio de novos referenciais de valores como, por exemplo, crianças e adolescentes como sujeitos de direitos, vivência saudável da sexualidade, concepção de família ampliada como forma de potencializar novos sentidos sobre esses conceitos, representando o Estado na execução de direitos sociais.

A família ampliada, composta de tios, primos, irmãos, vizinhos adultos que podem, nesses casos, vir a ser responsáveis ou tutores dos adolescentes, contribui para a construção de fator de proteção ao compor novas redes de vínculos afetivos e de confiança para as adolescentes. No entanto, para que tanto instituições e seus profissionais quanto pessoas do convívio familiar tornem-se mediadores deste novo processo de (re)invenção do sujeito, faz-se necessário uma cultura de reconhecimento do adolescente como sujeito 
pensante e participativo, mas que por estar em condição peculiar de desenvolvimento necessita de uma rede de apoio qualificada, a fim de contribuir para seu bem-estar e, consequentemente, para uma vivência de cidadania.

\section{Referências}

AGÊNCIA DE NOTÍCIAS DOS DIREITOS DA INFÂNCIA - ANDI. Glossário. Disponível em: <http://www.andi.org.br>. Acesso em: 20 set. 2008.

AGUIAR, W. M. J. Consciência e atividade: categorias fundamentais da psicologia sóciohistórica. In: BOCK, A. M. B.; GONÇALVES, M. G. M.; FURTADO, O. (Org.). Psicologia sóciohistórica: uma perspectiva crítica em psicologia. São Paulo: Cortez, 2001. p. 95-110.

ÀRIES, P. História social da criança e da família. 2. ed. Rio de Janeiro: LTC, 2006.

AZEVEDO, M. A.; GUERRA, V. N. de A. (Org.). Crianças vitimizadas: a síndrome do pequeno poder. São Paulo: Iglu, 1989.

BRASIL. Lei Federal 8.069 de 13 de julho de 1990. Dispõe sobre o Estatuto da Criança e do Adolescente e dá outras providências. Disponível em: <http://www.planalto.gov.br/ ccivil_03/LEIS/L8069.htm>. Acesso em: 20 ago. 2011.

Resolução no 196, de 10 de outubro de 1996. Aprovar as seguintes diretrizes e normas regulamentadoras de pesquisas envolvendo seres humanos. Disponível em: <http://www.datasus.gov.br/conselho/resol96/RES19696.htm.>. Acesso em: 20 ago. 2011.

Ministério de Combate à Fome e Assistência Social. Política Nacional de Assistência Social. Brasília, 2004.

CEDECA - CENTRO DE DEFESA DA CRIANÇA E DO ADOLESCENTE. Direitos de crianças $e$ adolescentes: guia de atendimento. Fortaleza: CEDECA, 2007.

KOLLER, S. H.; MORAIS, N. A.; SANTOS, E. C. Adolescentes e jovens brasileiros: levantando fatores de risco e proteção. In: LIBÓRIO, R. M. C.; KOLLER, S. H. (Org.). Adolescência e juventude: risco e proteção na realidade brasileira. São Paulo: Casa do Psicólogo, 2009. p. 17-56.

MARANHÃO, J. H. Os olhares da graduação de serviço social sobre a violência sexual contra crianças e adolescentes. In: SEMANA UNIVERSITÁRIA DA UECE, 13., 2008, Fortaleza. Anais... Fortaleza, 2008. Disponível em: <http://www.uece.br/propgpq>. Acesso em: 14 jan. 2011.

MOLAS, A. La clínica y la familia em el campo de la violência. In: ETCHEVERRY, G.; PROTESONI, A. L. Derivas de la psicologia social universitária. Montevideo: Edicciones Levy, 2009. p. 371-393. 
PALÁCIOS, J.; OLIVA, A. A adolescência. In: COLL, C.; PALÁCIOS, J.; MARCHESI, A. (Orgs). Desenvolvimento psicológico e educação. 2. ed. Porto Alegre: Artmed, 2004. v. I, p. 309349.

SAFFIOTI, H. I. B. A síndrome do pequeno poder. In: AZEVEDO, M. A.; GUERRA, V. N. A. Crianças vitimizadas: a síndrome do pequeno poder. São Paulo: Iglu, 1989. p. 13-21.

SANTOS, M. S.; XAVIER, A. S.; NUNES, A. I. B. L. Psicologia do Desenvolvimento: teorias e temas psicológicos. Fortaleza: Líber Livro, 2008.

UNESCO - ORGANIZAÇÃO DAS NAÇÕES UNIDAS PARA A EDUCAÇÃO, A CIÊNCIA E A CULTURA. Políticas de/para/com juventudes. Brasília: Unesco, 2004.

VYGOTSKI, L. S. Obras escogidas. Madrid: Visor, 1995. Tomo III. 